Martin D. Henry (ITQ, vol. 65/1, 2000, 3-12) [revised]

\title{
Original Sin: A Flawed Inheritance
}

The doctrine of original sin has left its negative mark not only on theology, but according to Nietzsche, on Western civilisation as a whole. Augustine generally takes the blame for this sombre tradition, not least because of his association of procreation with the transmission of original sin. Despite its apparent endorsement of pessimism, does the doctrine nonetheless conceal an unexpected message of hope? [Editor]

To judge from some weighty commentators on Christianity in the past two centuries, the doctrine of original sin (and the corresponding promise of redemption) is not simply one of Christianity's essential teachings, but its very core and centre, that without which it would lose its integrity and coherence. Schopenhauer, for one, in his best-known work, The World as Will and Representation, asserts as self-evident that original sin is at the centre of Christianity: 'The great truth that really constitutes the heart of Christianity is the doctrine of original sin (affirmation of the will) and redemption (denial of the will); whereas everything else is mostly only wrapping and covering, or simply accessories. ${ }^{1}$ And in his other main work, Parerga and Paralipomena,

\footnotetext{
'Wirklich ist die Lehre von der Erbsünde (Bejahung des Willens) und von der Erlösung (Verneinung des Willens) die große Wahrheit, welche den Kern des Christentums ausmacht; während das übrige meistens nur Einkleidung und Hülle oder Beiwerk ist' (Die Welt als Wille und Vorstellung, Vol. 1, Bk. 4, in Sämtliche Werke, ed. Wolfgang Frhr. von Löhneysen, Darmstadt, 1974, vol. I, 550 [vol. 1 was first published in 1819; the passage quoted was added to the second edition in 1844; ibid., 721]. The identification of original sin with the will is also taken as obvious by George Santayana: 'Existence itself is not a good, but only an opportunity. Christians thank God for their creation, preservation, and all the blessings of this life, but life is the condition and source of all evil, and the Indians thank Brahma or Buddha for lifting them out of it. What metaphysical psychologists call Will is the great original sin, the unaccountable and irrational interest which the spirit takes, when it is incarnate, in one thing happening rather than another . . ' (G. Santayana, 'Carnival', in Soliloquies in England and Later Soliloquies, London, 1922, 139f.). That original sin does have an inalienable link with
} 
he reiterates his basic definition of Christianity: 'Augustinianism, with its dogma of original sin and all that is connected with it, is . . real Christianity, properly understood. ${ }^{2}$

Closer to our own times is the unrelenting pessimism of Cioran who, like Schopenhauer, fastens on original sin as Christianity's crown jewel:

The eminent cleric was poking fun at original sin. 'That sin is your meal ticket. Without it, you'd die of hunger, for your ministry would then no longer have any meaning. If man is not fallen from the very beginning, why did Christ come? to redeem whom and what?' To my objections, his only response was a condescending smile.

A religion is finished when only its adversaries try to preserve its integrity. ${ }^{3}$

Between these two figures in time, though not in outlook, is Nietzsche, originally a fervent admirer, but finally an outright critic, of Schopenhauer. For although both German thinkers saw Christianity as endorsing, indeed fostering, a bleak view of earthly existence, Nietzsche, unlike Schopenhauer, castigates Christianity for its presumed antagonism towards life ${ }^{4}$ and culture. ${ }^{5}$ It is true, of course, that Nietzsche rarely mentions the term 'original sin', ${ }^{6}$ except obliquely

human free will is certainly part of Catholic doctrine, albeit not as Schopenhauer or Santayana may have conceived it.

2 'Der Augustinismus mit seinem Dogma von der Erbsünde und, was sich daran knüpft, ist . . . das eigentliche und wohlverstandene Christentum' (Parerga und

Paralipomena, Bd. II, 1851, §180, in Sämtliche Werke, 1976, vol. 5, 457).

$3 \quad$ E.M. Cioran, Aveux et Anathèmes (Paris, 1987), 29.

4 'What sets us apart is not that we recognize no God, either in history or in nature or behind nature - but that we find that which has been reverenced as God not "godlike" but pitiable, absurd, harmful, not merely an error but a crime against life. . .." (The Anti-Christ, §47, tr. R.J. Hollingdale, Harmondsworth, 1990, 172f.).

5 'Christianity robbed us of the harvest of the culture of the ancient world, it later went on to rob us of the harvest of the culture of Islam' (The Anti-Christ, §60, 193).

6 There is, for example, a passing reference to the topic in Human, All Too Human, where 'original sin', along with other Christian teachings, is summarily dismissed as illusory, though no less potent a historical force for being 'untrue'. Speaking of the Conference of Ratisbon (Regensburg), called in 1541 to seek an accommodation between Catholics and Protestants, Nietzsche writes: '[C]onsider . . . that none of the propositions over which they were then contending in Regensburg - neither that of original sin, nor that of redemption by proxy, nor that of justification by faith - is in any way true or has anything whatever to do with truth, that they are now all recognized as undiscussable: and yet on their account the world was set in flames, that is to say on account of opinions to which nothing real corresponds ...' (F. Nietzsche, Human, All Too Human, 
or backhandedly, in order to turn the tables on Christianity. ${ }^{7}$ Thus, in his 'exegesis' of Genesis 3 he uses the term with concentrated sarcasm to vent his disgust at what he takes to be Christianity's hostility towards knowledge ('Science is the first $\sin$, the germ of all sins, original $\sin ^{8}$ ); or again, he impishly exploits its meaning in expressing his contempt for theology ${ }^{9}$; or finally, he invokes the notion in censuring Christianity's allegedly killjoy spirit. ${ }^{10}$ One will not therefore find in Nietzsche any earnest, straightforward or sustained discussion of the theological dogma of original sin, but what one will find is a robust rejection of any pessimistic assessment of human existence, for which 'original sin' has long been a popular shorthand expression in Western culture.

At this point one might ask whether Nietzsche's violent indictment of Christianity's perceived aversion to life ${ }^{11}$ and to its means of transmission, is not perhaps less a condemnation of 'Christianity' than of the Augustinian understanding of Christianity - assuming of course that the two can be disentangled - which highlighted the significance of original sin for human existence. Certainly, the ominous notion that original sin was transmitted by the procreative act was anathema to Nietzsche. But this notion, which begins to appear with Tertullian and is generally seen to have fully crystallised with Augustine, ${ }^{12}$ does not have any obvious backing in the New Testament.

Volume Two, Part One, ‘Assorted Opinions and Maxims’, §226, tr. R.J. Hollingdale, Cambridge, 1986, 270).

Cf. The Anti-Christ, §61, 195: 'the old corruption, the peccatum originale, Christianity'. The Anti-Christ, §48, 174.

'Theology, or the corruption of reason by “original sin” (Christianity)' (Twilight of the Idols, 'Expeditions of an Untimely Man’, §2, tr. Hollingdale, Harmondsworth, 1990, 77).

'As long as men have existed, man has enjoyed himself too little: that alone, my brothers, is our original sin!' (Thus Spoke Zarathustra, Part Two, 'Of the Compassionate', tr. Hollingdale, Harmondsworth, 1986, 112).

He saw the early Christians who eventually took over the Roman Empire, who 'sucked [it] dry', as 'cunning, secret, invisible, anaemic vampires!' (The Anti-Christ, §59, 193).

'Tertullian, St Cyprian and St Ambrose taught the solidarity of the whole human race with Adam not only in the consequences of his sin but in the sin itself, which is transmitted through natural generation ...' (The Oxford Dictionary of the Christian Church, ed. F.L. Cross and E.A. Livingstone, Oxford, 19973, 1196). The contribution of St Augustine (for Nietzsche, one 'of the Christian agitators', The Anti-Christ, § 59) to the development of the doctrine of original sin and to its tight binding to matters sexual, 
It is thus arguably - though not necessarily ${ }^{13}$ - the Augustinian interpretation of original $\sin ^{14}$ which is under attack when Nietzsche makes his strident criticism of Christian attitudes to sexual relations: 'It was only Christianity, with ressentiment against life in its foundations, which made of sexuality something impure; it threw filth on the beginning, on the prerequisite of our life . . . ${ }^{15}$ In this context it is of some interest to see Nietzsche throwing the dogma of the Immaculate Conception into the fray in support of his case but,

has frequently been commented on. See, for example, Peter Brown's helpful discussion of this question in his Augustine of Hippo, London, 1967, 387ff. It should, however, be said that Tertullian's views on original sin appear to have differed significantly from St Augustine's in that, while 'Tertullian believed that every soul is afflicted with evil through a fault of origin, this evil is due, not to descent from Adam, but to infection from pagan sources before and after birth' (G. Watson, in a review of AugustinusLexikon, Vol. I. Fasc. 4, ed. C. Mayer et al., Basel/Stuttgart, 1990, in ITQ, 58, 1, 1992, 82). Augustine is perhaps more democratic.

13 It would take us too far afield to enquire whether Nietzsche is in fact an entirely reliable guide to any history of Christian attitudes to sexuality. His sweeping, polemical remarks may be more revelatory of his disgust at the mores of his own society than completely accurate guides to past attitudes. When he excoriates figures from the past, his interest is clearly not chiefly historical. It is, rather, that such figures symbolise conveniently for him attitudes he reviles in the present, and views as typical of Christian culture. Concerning Augustine, it would be, as Peter Brown carefully argues, a serious misrepresentation of his thought to imagine that he had an instinctive hatred or distrust of the body, or of the material order, as such. What dominated Augustine's thinking was the unbudgeable conviction that the Fall represented an act of disobedience by Adam, whereby the soul acted in disharmony with the body, the will being unable to control the actions of the body. This discord Augustine saw mirrored graphically in the way the will was now unable to control sexual drives, whereas in Paradise theoretically - it would have been able to do so before the Fall. But for Augustine 'concupiscentia carnis' is in no sense restricted to the sexual arena: 'Concupiscence was a dark drive to control, to appropriate, and to turn to one's private ends, all the good things that had been created by God to be accepted with gratitude and shared with others. It lay at the root of the inescapable misery that afflicted mankind. Sexual desire was no more tainted with this tragic, faceless concupiscence than was any other form of human activity' (P. Brown, The Body and Society. Men, Women and Sexual Renunciation in Early Christianity, London, 1990, 418).

14 On the undoubted complexities of Augustine's position on the transmission of original sin, see J.M. Rist, Augustine. Ancient thought baptized, Cambridge, 1994, Appendix 2 ('Traducianism, creationism and original sin'), 317-320. Despite the abiding obscurities that complicate Augustine's thought on the topic, Rist nevertheless concludes: 'Of the connection between fallen sexual intercourse and the transmission of original sin there can be no doubt'; only the manner in which 'the "immaterial quality" of sinfulness' could be transmitted by 'fallen sexual intercourse' remained for Augustine mysterious (ibid., 319).

15 Twilight of the Idols, 'What I Owe to the Ancients', §4, 120 (cf. Walter Kaufmann, Nietzsche, Princeton, 1974, 223). 
ironically, misunderstanding it in a way in which it has in fact frequently been misapprehended. ${ }^{16}$ When he asks: 'And is it allowable to be a Christian as long as the origin of man is Christianized, that is to say dirtied, with the concept of the immaculata conceptio? . . . ', ${ }^{17}$ he seems - as in an earlier passage of the same work where he claims that with 'a dogma of "immaculate conception"” Christianity 'has thereby maculated conception, 18 - to have confused the doctrine of the virgin birth, or rather the virginal conception of Jesus, with the doctrine of the immaculate conception of Mary. ${ }^{19}$

It is ironic that Nietzsche should have fallen into this error, since the dogma of the Immaculate Conception actually points in the direction in which he himself was so resolutely determined to look. And it is not pedantic hairsplitting to point out his mistake. For by defining Mary's conception as 'immaculate', and in this particular way asserting her freedom from original sin, Catholic doctrine was actually ruling out any intrinsic linkage between original sin and the act of procreation. Put simply, in Mary's case there was an act of procreation, but no transmission of original sin. Thus, whatever the source or nature of original sin may be, from which Mary was preserved, it cannot be located in the specific act of generation of human life. The whole point of the doctrine of the immaculate conception is to affirm Mary's freedom from original sin always, from the very start - or 'origin' or 'conception' - of her life, just as the point of the dogma of original sin is to stress its applicability to the whole human race from the start - or 'origin' - of the human community. But perhaps inevitably in the case of the Immaculate Conception, emphasis came to fall on the term 'conception', a term inextricably linked with sexuality, just as in the case of original sin, emphasis had come to fall on the notion of the origins of human life, a notion that, at least until recently, has also been universally tied to the sexual urge.

It would, admittedly, be disingenuous to deny that historically the linkage between original sin and the sexual origins of human beings has been made, or at least has been believed to exist, and this confused and confusing belief has unquestionably bedevilled Christian attitudes to sexuality down through the

\footnotetext{
See, for example, Luis Buñuel, My Last Breath, tr. Abigail Israel (London, 1994), 44. The Anti-Christ §56, $185 f$. The Anti-Christ \$34, 157. Cf. the commentary to The Anti-Christ §34, in F. Nietzsche, Sämtliche Werke. Kritische Studienausgabe, ed. G. Colli and M. Montinari (Munich/Berlin, 1988), vol. 14, 442.
} 
centuries. ${ }^{20}$ The tale of Adam and Eve, and God and the Serpent in the Garden of Eden, has exercised many kinds of minds in many kinds of ways over the centuries, but as one recent commentator has observed: 'Sexuality . . . has continued to slip falsely into the story's gaps. The fruit of the tree was an aphrodisiac, in Augustine's opinion, and caused sexual lust to conquer our will. Many artists, including Dürer, placed a cat, about to pounce, beneath the tree from which our parents ate; cats (respected by Muslims) had become symbols of sexual desire in early Christian literature. ${ }^{21}$

The dogma of the Immaculate Conception should, ideally, have acted as a barrier against any unhelpful identification of the transmission of original sin with procreation itself. Sadly, however, it may only have intensified that identification. Indeed one indication of this may be the already mentioned misapplication of the dogma to the doctrine of Jesus' virginal conception instead of to Mary - that so frequently and, it would seem, almost naturally occurs. This error tends to reinforce in popular belief the suspicion that sexuality as such is 'ungodly', and, being ineradicable, must be the cause of humanity's perennial ills. In short, the felix culpa ('happy fault') has had a most unhappy history.

Rather than being about sexuality, the dogma of original sin - as already intimated $^{22}$ - would seem to be about the role of human freedom in the economy of salvation. The burden of the dogma is not just to state that the consequences of free human decisions can be catastrophic, but that they can - in some inscrutable way - lead to the attainment of a higher good than that which was lost by sin. Put in mythical terms: the wonder of Paradise turns out to be illusory, or - as Nietzsche mischievously puts it - it turns out to be boring, ${ }^{23}$ and humanity is then driven to look elsewhere for fulfilment. That the very idea of

20 To make this claim, is not, of course, to suggest that, were the connection between original sin and human sexuality to be broken, human sexuality would then emerge with a regained innocence. Original sin, as a doctrine about the historical condition of human beings in relation to God, would of course continue to have relevance to all aspects of human existence, including sexuality, but the unsustainable connection between sexual intercourse and the transmission of original sin would be removed. Robin Lane Fox, The Unauthorized Version. Truth and Fiction in the Bible (Harmondsworth, 1992), 26.

22 See n.1 above.

23 The Anti-Christ, §48, 174. 
paradise could be boring is implicit in Goethe's well-known lines: 'Anything in the world can be endured, except a series of wonderful days', ${ }^{24}$ a notion rehearsed - not surprisingly, perhaps - by the Reformer Martin Luther, ${ }^{25}$ and taken up later by Hegel, ${ }^{26}$ who like Nietzsche was himself deeply steeped in the Lutheran tradition. Expulsion from Paradise, however, does not turn out to be an unmitigated disaster, but rather the necessary step humanity must take in order to reach God.

Such, needless to say, is not the language of history or science, but of faith and hope. Original sin is what makes some of our reactions to the universe we find ourselves inhabiting so inadequate as to be destructive (how could it be otherwise, since we didn't make the world?). But at the same time no lapse is so irredeemable that God cannot use it for our benefit, in the long run. In saying this, one is not reducing human beings to playthings either of fate or of God. On the contrary, belief in original sin underlines our freedom and our significance, since it places responsibility for our situation on our own shoulders, ${ }^{27}$ but also indirectly hints that there is a reality over and above our responsibility, for if there were not, to what or to whom would we feel responsible? This realisation relativises our plight, without demeaning it, and lets us taste the relief of being tolerated, perhaps even desired, by what so completely transcends us. In other words, original sin is not a symbol for the horror of existence, as if somehow we should not be here. The twelfth-century thinker, Adelard of Bath, was surely closer to the truth than the many exuberant pessimists through the ages, when he 'wrote that if humans neglect coming to know the beauty of the universe in

\footnotetext{
24 'Alles in der Welt läßt sich ertragen,/Nur nicht eine Reihe von schönen Tagen' (tr. David Luke, Goethe, The Penguin Poets: Harmondsworth, 1972, 287).

25 See Georg Büchmann, Geflügelte Worte, ed. W. Hofmann (Frankfurt/M-Berlin, 1993), 128.

26 Hegel writes, not that paradise is specifically 'boring', but that 'the state of innocence, the paradisaical condition, is that of the brute. Paradise is a park, where only brutes, not men can remain' (from The Philosophy of History, quoted by J.C. Livingston, Modern Christian Thought. From the Enlightenment to Vatican II, New York, 1971, 151).

27 Cf. Gregory Shaw, art. 'The Fall', in Bruce M. Metzger and Michael D. Coogan (eds.), The Oxford Companion to the Bible (Oxford, 1993), 223: 'The biblical myth of the Fall is similar to other legends that contrast humanity’s present state of suffering with an earlier time of perfection, a lost paradise or golden age. The biblical narrative is unique, however, in implying that humanity's degradation was indirectly caused by its own free choice.'
} 
which they live, they would deserve to be cast out from it like guests incapable of appreciating a home in which hospitality is offered them. ${ }^{28}$

Adelard's is clearly a rather different account of the human condition from that proposed by many other earlier and later Christian thinkers. Some of the thinkers of the early Church were possibly forced by their desire to refute the ancient Gnostics, who identified Creation with the Fall itself, into conceding too much to the Gnostic position, in order to convince waverers attracted by Gnosticism's account of some undeniable, if unpalatable, truths of existence. Important similarities between the early Christians and their Gnostic rivals are undeniable, and scarcely surprising. Both were, after all, fighting for the same territory, and the suffering of the same world stared both in the face. Christianity, furthermore, imbibed the pessimism of late antiquity ${ }^{29}$ as of course did the Gnostics, even if - doctrinally at least - the Christians did not do so as wholeheartedly as their rivals. Whether from the vantage point of today one 'blames' the ancient battle against Gnosticism, or even Judaism or Hellenism for the pessimistic strain in Christian culture is perhaps a rather pointless exercise, since the human condition as such has always offered plenty of evidence for pessimism and despair to all who wish to brood on it.

Moreover, to suggest - as it may be tempting to do - that Augustine injected into the bloodstream of Western culture a poisonous pessimism which has been convulsing that culture at intervals ever since, is a travesty of Augustine's thought and almost insultingly inadequate to the restless, probing subtlety of his mind, to say nothing of the overarching, guiding vision of his faith and hope. Even in his final 'years of bitter frustration', Peter Brown writes, 'Augustine never abandoned the hope against which he judged, ever more sadly, the present misery of the human race. It was still a hope for unity. A shattered

28 Matthew Fox, in the 'Afterword to the 1990 Edition' of Original Blessing (Santa Fe, originally published 1983), referring to M.-D. Chenu, Nature, Man and Society in the Twelfth Century (Chicago, 1968), 13.

29 Cf. Basil Willey, Christianity Past and Present (Cambridge, 1952), 69: 'There is little doubt, I think, that doctrines often take their colouring, and derive their cogency, from historical circumstances. It has been said, for example, that the doctrine of Original Sin arose from the Weltschmerz of antiquity. The work of St Augustine was contemporaneous with the sack of Rome in A.D. 410, and the Vandals were besieging Hippo when he died. The major statement of the doctrine, then, was the work of an epoch of confusion and despair.' 
harmony would be regained at the end of time. In his sermons we can sense the momentum of an unwearied heart. The fatal flaw of concupiscence would not have seemed so tragic to Augustine, if he had not become ever more deeply convinced that human beings had been created to embrace the material world. The body was a problem to him precisely because it was to be loved and cherished'. ${ }^{30}$ A not insignificant token of Augustine's affirmation of life is, not unsurprisingly in one who obviously so much enjoyed writing, what Brown calls 'his unfailing literary aplomb', ${ }^{31}$ that never deserted him, not even in extremis. Hence the judgement often heard that, regrettably, it 'was not Origen but Augustine who determined the future pattern of Western Christianity', ${ }^{32}$ is, though understandable, perhaps also slightly unfair to the Doctor of Grace.

In the event, certainly, propelled in an (inevitably?) somewhat one-sided fashion by Augustine's irresistible genius - who has the time or energy to attend to all the nuances? - Christianity, or Western Christianity at any rate, absorbed willingly, indeed enthusiastically, the pessimism of late antique culture and baptised it for future generations in the concept of 'original sin'. It is ironic that precisely this concept should have taken on such significance in Christian culture, since ' $[\mathrm{t}] \mathrm{he}$ idea that some great sin lay behind the misery of the human condition was shared by pagans and Christians in Late Antiquity', ${ }^{33}$ whereas what early Christianity set out to do was to present itself as a new beginning, to differentiate itself significantly from the pagan world. However, apologists cannot always be choosers, and some strong point of contact always has to be found between the Christian message and the culture it is to address. To have resisted the temptation to appeal to original sin in the world of late antiquity, in order to promote Christianity, would have been like looking a gift horse in the mouth.

In the shadow of Augustine's towering, inescapable achievement, Western Christianity - in some extreme expressions - came to experience life

30 P. Brown, The Body and Society, 425.

31 Ibid., 423.

32 E.R. Dodds, Pagan and Christian in an Age of Anxiety (Cambridge, 1965), 132. Curiously enough, Dodds earlier points out (p. 23, n.4) that both the Christian Origen and the pagan Plotinus refused to celebrate their birthdays, since they both viewed birth as something of 'a misfortune'. Who were the real pessimists?

33 P. Brown, Augustine of Hippo (London, 1967), 388. Brown mentions Cicero, cited in Contra Julianum, IV, xiii, 78, and, to illustrate further the point at issue, quotes (ibid.) from Augustine's de moribus ecclesiae catholicae (I), xxii, 40: 'The Ancient Sin: nothing is more obviously part of our preaching of Christianity; yet nothing is more impenetrable to the understanding.' 
almost as a process of atonement for the crime of being born, from which death promised release into heaven for the chosen few, and threatened descent into hell for the 'massa damnata'. ${ }^{34}$ This world was only a vale of tears, to be traversed en route to a better place, as endless exhortations on the theme de contemptu mundi never ceased to hammer home. The much discussed gloom of the Reformers in the sixteenth century and of the Jansenists and Puritans in the seventeenth, is symptomatic of certainly one strand in Augustinian Christianity, and stands out in retrospect in all its grimness when contrasted with, say, some of the happier aspirations of the eighteenth century.

But the sunnier moments of Western culture seem the exception rather than the rule. It is hardly surprising, then, that someone as imbued with Catholic culture as the sceptical philosopher George Santayana went so far as to wonder whether even classical Christian mystics were not at heart anonymous, as it were, life-refusing nihilists: 'Has the belief in heaven been more often a longing not to live, than to live forever? I almost think so. And you know the verses of St. Theresa and St. John of the Cross: "Muero porque no muero.", 35

And yet a false, even a perniciously false, interpretation of a belief does not necessarily cancel its entire meaning. Hence, to reject a tendentious account of original sin, which would link it too exclusively to the sexual dimension of human nature, or which would see it as a charter for unbridled pessimism, is not to evacuate the doctrine of all meaning. Rather it is to open up the possibility of reaching a less inadequate understanding of the dogma than the one rejected. It

34 This was officially restated in the fifteenth century, as D.L Edwards reminds us: 'In 1439 the council of Florence taught that all unbaptized adults must go to hell even if they have committed no personal sin, because they have inherited "original" sin from Adam' (Christianity. The First Two Thousand Years, London, 1997, 175). Hell, though, the same council pointed out, was, like heaven, not without gradations: '[T]he souls of those who depart this life in actual mortal sin, or in original sin alone, go down straightaway to hell to be punished, but with unequal pains', Norman P. Tanner, S.J., ed., Decrees of the Ecumenical Councils, London, 1990, Vol. I, 528; cf. ibid., 578, where we read that the council also 'firmly believes, professes and preaches that all those who are outside the catholic church, not only pagans but also Jews or heretics and schismatics, cannot share in eternal life and will go into the everlasting fire which was prepared for the devil and his angels [Mt 25,41], unless they are joined to the catholic church before the end of their lives . . .'. Still some way down the road was the Calvinist version of the 'Good News', as double predestination, considered by some to be the final, unambiguous and uncompromising statement of Augustine's theology of grace (see J. Pelikan, The Melody of Theology, Cambridge, Ma., 1988, 108f.).

35 The Letters of George Santayana, ed. with an intro. and commentary by Daniel Cory (London, 1955), 395 (in a letter to Corliss Lamont of 8 June, 1950). 
is to argue, not that 'original sin' be replaced by 'original blessing', ${ }^{36}$ but that 'original sin' might be better understood, following Kolakowski, as a shorthand way of 'making people acutely aware of their contingency and the finitude of life, of the corruptibility of the body, of the limitations of reason and language, of the power of evil in us'. ${ }^{37}$ As such, original sin points to the need for, and possibility of, redemption. The need is clear enough, though whether the possibility will be realised or not depends, necessarily, not entirely on us, as we are only part of the picture. But the possibility of redemption for mankind which the dogma of original sin - albeit awkwardly, and even ambiguously (though thereby perhaps not altogether inappropriately) - attempts to adumbrate, may have been first glimpsed through the blurred focus of Christianity's verdict on human existence, a verdict reached in the person of Jesus, the crucified innocent victim who redeems our humanity.

For Christianity, man is caught between the impossibility of reaching happiness unaided, and the equally real impossibility of giving up on the quest for happiness definitively. Original sin, which frustrates the achievement of human happiness in any deliberately planned, self-made way, and the indeterminate nature of man ('made in the image of God'), which leaves open the possibility of endless human striving for happiness, these twin constants of existence together account for the eternal recurrence of tragedy in human history: 'Es irrt der Mensch, so lang er strebt', as Goethe's famous line has it. ${ }^{38}$

Just as important, however, as seeing original sin in the light of redemption, perhaps even more so, is to see original sin in the light of the doctrine of creation. For, to see original sin in the context of creation is to give it its true significance, which is to point to man's inextricable link with God, no matter what happens in history. For those who have eyes to see, that link - since we believe God is good - will be experienced, more often than not, as a 'falling short' of the glory of God. That is the Fall, and not some pre-cosmic or prehistorical catastrophe, which we were helpless to prevent and for which we must forever be punished. But to 'fall short' is still to be dimly aware of the goodness not just that lies ahead, but that underlies and surrounds everything. That this

This latter is a belief that has traditionally been expressed by the doctrine of creation.

L. Kolakowski, Religion (Oxford, 1982), 200.

Faust, Part One, 'Prologue in Heaven' ('For man must strive, and striving he must err', tr. Philip Wayne). 
goodness is obviously not our possession, even when we sense it, is why it has usually in Christian tradition been referred to as grace. And that grace doesn't cease to be, simply because we don't possess it, is the 'reason' why it is reasonable to hope in redemption. The relief of knowing that there is something to fall short of, is perhaps the meaning of religious peace. The suspicion that the 'falling short' will be eternal, that we are doomed to share the fate of Tantalus, may cloud that peace, but cannot destroy it. Sufficient unto the universe is the clarity thereof, even if it is a 'cloud of unknowing'.

This universe in which our lives unfold reveals its value, not its worthlessness, in the light of original sin. The 'majestic sadness' $\left(\right.$ Racine $\left.^{39}\right)$ of human history would make no sense, if human life were of no significance. For, life's significance is - paradoxically - underlined, not undermined, by the potential for suffering our decisions can unleash. This awesome discovery narrated paradigmatically by the author of Genesis - is re-enacted by the great masters of Tragedy, but it clearly goes beyond the scope of mere discursive prose to explain. For Christian faith, the beauty of original sin lies in its being an oblique demonstration of the indestructible value of that creation in which we 'live and move and have our being', and also in its being the key which opens the gate out of Paradise and sets humanity on the hard road to Heaven. ${ }^{40}$

39 In using this phrase, I am of course doing violence to its original context ('Préface' to Bérénice) where the expression refers to 'the essential pleasure of tragedy' (John Campbell, in private communication).

40 For some of the ideas in this article I am indebted to John Campbell, 'Racine and the Augustinian Inheritance: The Case of Andromaque’, French Studies, Vol. LIII, No. 3, July, 1999, 279-291, a powerfully argued refutation of traditional, Jansenist readings of Racine. 